\title{
The darkness-within-the-light of contemporary fiction: Agamben's missing reader and Ben Lerner's 10:04
}

Ben Davies, University of Portsmouth

\begin{abstract}
The role of reading and the reader in Giorgio Agamben's 'What is the Contemporary?' is ambiguous. Rather than examining the importance of reading he emphasises, Agamben explores what it means to be contemporary. Reading Ben Lerner's 10:04 in the light (and darkness) of Agamben's essay, I argue both that the essay can be read as a theory of 'contemporary reading' and that 10:04 reflects its own contemporariness. 10:04 creates forms of contemporary relationality through a poetics of light and darkness, and positions its reader within a caesural space, in which she is proximate to, and distanced from, the text. This reading therefore opens up an understanding of the contemporary reader that is relational, not historical. Correlatively, 10:04 also raises problematics of the study of the contemporary novel more widely. I shall read a moment of deletion, for instance, to argue that analysis of the contemporary novel must include the field's un-written materials. I shall likewise analyse 10:04's interest in the reader to argue that non-readers also form part of the field and deserve critical attention. Ultimately, 10:04 unveils the darkness-within-the-light of the contemporary novel and reader, both of which are missing from Agamben's essay.
\end{abstract}

\section{Keywords}

Agamben, Lerner, Contemporary, Reading, Time, Darkness and Light 
Giorgio Agamben's essay 'What is the Contemporary?' (2008) and Ben Lerner's novel 10:04 (2014): two texts, both with an emphasis on reading and readers, optics and seeing, and the confusion of light and darkness. But whereas Lerner's novel repeatedly considers and invokes reading and readers, Agamben omits these aspects in his influential essay, despite situating them both as being central to its success. ${ }^{1}$ Bringing these two texts together and reading them in each other's darkness as well as their light, I shall focus my vision on Agamben's essay - particularly his crucial oversight - and 10:04's contemporariness, to argue for contemporary reading, readers and fiction to be seen not in the light of historical specificity or periodicity, but in the light of darkness and relationality. In so doing, this essay takes up in particular one of the central and most invoked metaphors of Agamben's essay, not to focus on the current ('contemporary') historical moment as, for instance, Peter Boxall does to argue for a different type of vision to navigate our present condition ${ }^{2}$; nor does it do so to discuss generally the opacity often invoked as part of an analysis of one's present. ${ }^{3}$ Rather, I read Agamben's essay and his own blind spots in order to cast them towards an investigation

\footnotetext{
${ }^{1}$ Discussing the essay's influence, Lionel Ruffel teasingly states that it 'is cited more often than it is read'. Brouhaha: Worlds of the Contemporary, trans. Raymond N. Mackenzie (Minneapolis and London: University of Minnesota Press, 2018), p. 72.

${ }^{2}$ Peter Boxall, 'Blind Seeing: Deathwriting From Dickinson to the Contemporary', New Formations, 89.90 (2016), pp. 192-211.

${ }^{3}$ For three recent discussions of this problematic, see: Peter Boxall, Twenty-First-Century Fiction: A Critical Introduction (Cambridge: Cambridge University Press, 2013); Daniel Lea, Twenty-First-Century Fiction: Contemporary British Voices (Manchester: Manchester University Press, 2017); and Theodore Martin, Contemporary Drift: Genre, Historicism, and the Problem of the Present (New York and Chichester: Columbia University Press, 2017).
} 
of the study of contemporary literature specifically in terms of reading and readers. Indeed, despite his central omission, Agamben's essay does offer a way into re-conceptualising contemporary reading and readers; correlatively, Lerner's novel is, I propose, a contemporary 'contemporary' text (or a 'meta-contemporary' text) that reflects (upon) its own relationality to the time it depicts. In the light of each of their shadows, these two texts, moreover, bring to the fore patternings of light and darkness that surround and comprise the study of contemporary literature - problematics that involve authors, readers, the un-read, and the unwritten. Rather than simply focusing on forms of light, scholars must, I propose, focus on contemporary literature's various shades and shadows, the field's darkness and blind spots, if we hope to be contemporary to and with the texts we study.

\section{Agamben and the contemporary reader}

For Agamben, being contemporary is fundamentally a spatiotemporal and relational matter. It concerns a 'special experience of time', which is neither chronological nor historical:

Those who are truly contemporary, who truly belong to their time, are those who neither perfectly coincide with it nor adjust themselves to its demands. They are thus in this sense irrelevant [inattuale]. But precisely because of this condition, precisely through this disconnection and this anachronism, they are more capable than others of perceiving and grasping their own time. ${ }^{4}$

\footnotetext{
${ }^{4}$ Giorgio Agamben, 'What is the Contemporary?', in What is an Apparatus? and Other Essays, trans. David Kishik and Stefan Pedatella (Stanford, CA: Stanford University Press, 2009), pp. 39-54 (pp. 47, 40). All further references are cited in the text.
} 
Throughout the essay, Agamben prioritises relational "“dys-chrony"' (p. 41) and noncoincidence, which involve a tension and paradox: being contemporary requires belonging to, and, at the same time, being somewhat distanced from, one's time. Indeed, Agamben's contemporary exists within a fracture, a caesura, that breaks up 'the inert homogeneity of linear time' (p. 52). From this position, he is able to 'perceive' and 'grasp' his time better than his 'contemporaries'. As a result of such relationality, the contemporary possesses, moreover, transformational agency; he is able to 'cite' history differently, to create his own temporal relations with past times, in ways others who are more 'in time' with their time cannot; not only is he able, Agamben insists, but the contemporary is unable not to respond in this way (p. 53).

Within his variations on the theme of the contemporary, Agamben draws emphatically upon the sense of sight as a guiding metaphor - one I shall hold on to in this essay. Exploring the realms of biology and astrophysics, Agamben explains that the darkness we see when we close our eyes, and the darkness we see in the sky, are forms of presence: our own "Off-cells" produce the darkness we see when we close our eyes, and the darkness we see in the sky is light from galaxies that will never reach us. ${ }^{5}$ Through these prisms, Agamben suspends the determinations of presence and absence, activity and passivity, and light and darkness. The contemporary, he proposes, is the one who sees darkness and light in one another: contemporaries 'do not allow themselves to be blinded by the lights of the

\footnotetext{
${ }^{5}$ Specifically referring to this astrophysical reading, Pedro Erber calls into doubt 'the accuracy of Agamben's information'. 'Contemporaneity and Its Discontents', Diacritics 41.1 (2013), pp. 24-48 (p. 43). Regardless of the 'accuracy' of Agamben's scientific knowledge, it is the metaphorical import of such images that concerns me in this essay.
} 
century, and so manage to get a glimpse of the shadows in those lights, of their intimate obscurity' (p. 45); inversely, Agamben claims, 'to perceive, in the darkness of the present, this light that strives to reach us but cannot - this is what it means to be contemporary' ( $\mathrm{p}$. 46).

Within the essay, the role and relationality of the reader are presented as fundamental. At the beginning, Agamben stresses the importance of the reader's relation to texts, stating that 'it is essential that we manage to be in some way contemporaries of these texts' (p. 39). This relationship is of such importance that he closes the opening section of the essay with a readerly exhortation:

The 'time' of our seminar is contemporariness, and as such it demands [esige] to be contemporary with the texts and the authors it examines. To a great degree, the success of this seminar may be evaluated by its — by our — capacity to measure up to this exigency. (p. 39)

The essay's demand, success, measure and evaluation all rest upon a type of reading: Agamben demands that readers be contemporary with the texts and writers under discussion. Indeed, the importance of this type of reading frames the essay, with the final sentence being: 'It is on our ability [...] to be contemporaries not only of our century and the "now," but also of its figures in the texts and documents of the past, that the success or failure of our seminar depends' (p. 54). At stake in this seminar: the ability to be contemporary with texts; to be a contemporary reader.

As Pedro Erber notes, however, Agamben does not address his opening questions, despite the way in which 'the question of contemporaneity is posed in terms of a hermeneutic 
and methodological problem'. ${ }^{6}$ Moreover, Erber criticises the way in which Agamben invokes (Western) texts simply for theoretical support, rhetorically asking: 'Isn't this precisely a way of refusing to be contemporary with those texts? In holding them at a distance, as objects of pious reverence and contemplation, is it not the very possibility of sharing their time that we renounce?'7 In Erber's assessment, Agamben's approach is a 'mode of distant and obedient relationship with the authority of tradition' ${ }^{8}$ More than piously invoking texts to advance his theoretical propositions and thereby not sharing their time (itself a somewhat limited interpretation of what contemporary reading could be), Agamben never discusses the role of the reader or reading, and he never elucidates a theory of contemporary reading. When he turns to Nietzsche's Untimely Meditations (1874) to begin his exploration of contemporariness, he only discusses this text to propose an initial definition of 'the contemporary'. At the end of the essay when he turns to 'reading' history, he likewise fails to develop a theory of contemporary readers or contemporary reading; rather, he advances his theory of contemporariness, stating that the contemporary 'is able to read history in unforeseen ways, to "cite it"” (p. 53, my emphasis). Whilst reading and citing are intimately bound up with texts and readers, Agamben's overall sense here is more general and metaphorical; it concerns not the reading of a text per se, but of history. Moreover, Agamben invokes the concept and practice of reading in this part of the essay only indirectly and without elaboration. Even when he refers to Michel Foucault's work - 'his historical investigations of the past are only the shadow cast by his theoretical interrogation of the present' (p. 53) - and Walter Benjamin's 'historical index', Agamben does not offer a theory

\footnotetext{
${ }^{6}$ Erber, p. 38.

${ }^{7}$ Erber, p. 43.

${ }^{8}$ Erber, p. 43.
} 
of contemporary reading. ${ }^{9}$ As if unable to do otherwise, Agamben is always staring at his intertexts' bright lights, unseeing their darkness.

This approach of mining works for conceptual support extends beyond the reading of the theoretical texts Erber mentions. Even in his most sustained reading in the essay of Osip Mandelstam’s 1923 poem 'The Century', Agamben does not reflect upon reading or readers, but focuses exclusively on the quintessential contemporariness he sees in the figure of the poet. ${ }^{10}$ Following the tradition of poet-as-seer, Agamben contends that the poet is the one who is truly contemporary because it is 'he who must firmly lock his gaze onto the eyes of his century-beast, who must weld with his own blood the shattered backbone of time' (p. 42). For Agamben, the poet occupies a privileged - if mortal - role and position; seeing the poet's contemporariness as a type of poetic agon, Agamben proposes that the poet is impelled to stare at his own broken time and to sit within a double fissure: the fractured vertebrae of the age (between the nineteenth and twentieth centuries); and the fracture between the poet's own lifetime and the historical time in which he finds himself. Given his visionary vocation and fractured position, the poet must simultaneously bring together and hold apart the age; 'he is

\footnotetext{
${ }^{9}$ Benjamin renders the idea of the dialectical image itself in terms of light and darkness, writing in The Arcades Project (c. 1927-40; 1982): 'It is not that what is past casts its light on what is present, or what is present its light on what is past; rather image is that wherein what has been comes together in a flash with the now to form a constellation'. The Arcades Project, trans. Howard Eiland and Kevin McLauhglin (Cambridge, MA and London:
} Belknap-Harvard, 2002), p. 463.

${ }^{10}$ For a comparative analysis of how Alain Badiou and Agamben both read this poem for their own theoretical ends, see William Watkin, 'The Time of Indifference: Mandelstam's Age, Badiou's Event, and Agamben's Contemporary', CounterText 2.1 (2016), pp. 85-99. 
at once that which impedes time from composing itself and the blood that must suture this break or wound' (p. 42). The imagery of suture marks the double nature of poetic wound work; the healed wound joins flesh but retains a scar, a mark of temporal rupture. As a figure who is 'non-coincident' with his age, the poet is the one who is able to create a caesura that at once provides a connection and a break; paradoxically, and potentially impossibly, he is tasked with 'impeding' and 'suturing', 'shattering' and 'welding', the 'broken vertebrae' of the age, holding in check simple chronological progression, whilst using his vision to provide some form of understanding of his age. The poet is the one who sits in the fracture; indeed, if he is to be contemporary, the poet 'is this fracture' (p. 42).

At no point in this reading of the poem, however, does Agamben consider his own relationship to the poem as a reader, how he is (or is not) contemporary to or with this text, the very demand he sets himself. Correlatively, he does not consider how the poem may (or may not) engender a sense of contemporariness with its reader, or between the reader and her time, age or century. Indeed, there is no analysis of the relation between poem and reader, in either historical or narratological terms. Rather, Agamben reads the poem to position the poet as one who has privileged access to contemporariness and to advance his second definition of the contemporary, as the one "who firmly holds his gaze on his own time so as to perceive not its light, but rather its darkness' (p. 44). Ultimately, then, Agamben's reading focuses purely on content and meaning, not relationality, even if the content of the poem itself concerns 'a reflection on the relation between the poet and his time [...] on contemporariness' (p. 41); a reading of relational content is a reading of content, not a relational reading. Moreover, it is a reading of the poet and the poem, not text-reader relations or the reader's contemporariness to the text. By his own measure, then, Agamben fails to be a contemporary of this text. He substitutes content and meaning for textual-temporal relationality, and a theory of the poet's contemporaneity for the practice of contemporary reading. 
Despite his failure to measure up to his own task, and to move beyond the mode of negative critique, Agamben's essay can, I argue, be read specifically as a way to rethink contemporary reading and contemporary readers. It opens up transhistorical ways to reconsider how a text may be 'contemporary', as well as how a reader may be contemporary to and with a text. Following Agamben's theory, but always remembering the shadow within his own essay (reading and readers), a contemporary text would be one that gazes at its time, seeing and revealing the darkness-in-the-light of its epoch, offering to its reader an 'intimate obscurity' (p. 45) with her present, her 'now'. A contemporary text would be one that does not straightforwardly coincide with its own historical time or adjust itself to its demands; rather, its singular relationship with its time would be marked by non-coincidence and 'dyschrony' (through, for example, disruptive forms and styles that create a break between the mode and the object of representation). Consequently, the contemporary text itself would be a type of caesura, a time and space of pause, rupture and meeting, bringing together, whilst also holding apart, its own temporalities, the temporalities of that which it takes to represent, and those of the reader as well. It thereby takes up the paradoxical task of shattering and welding time: it is itself temporal, but can, through its modes of representation and the 'intimate obscurity' it creates with its reader, also check and impede time and create discontinuity within homogenous, linear time. Within this paradoxical caesural space, such an effect and form of relationality will be further heightened by the play of citation (one aspect of reading Agamben does consider); a contemporary text will bring together different texts, and thereby times, in ways that have transformational potential. 
The reader of such a text will be within a textual fracture - the vertebrae between her and the text, and that between represented time and representational time. ${ }^{11}$ Rather than being defined in relation to chronological and/or historical time, or its content (representations of 'now', the present moment, etc.), a contemporary text would be one that creates and emphasises a certain positionality and relation with its own time and the reader through the tension between proximity and distance, non-coincidence, 'dys-chrony'. Consequently, it becomes possible to make a distinction between merely 'present' literature and ‘contemporary' literature, between texts that are simply written now (or just then) and ones whose poetics, modes of representation, forms and structures create a certain ('contemporary') relationality with their own time and with the reader. ${ }^{12}$ Moreover, a text that

${ }^{11}$ Referring to the work of Gustave Guillaume, Agamben analyses the way in which mental representations of time take time; they are not pre-formed. As a result of this 'operational time', synchronicity between time and its representation is impossible. The Time That Remains: A Commentary on the Letter to the Romans, trans. Patricia Dailey (Stanford, CA: Stanford University Press, 2005), pp. 65-7. With a specific focus on the contemporary, Thomas Docherty offers a related argument, proposing: 'A presentation of the present must always involve a re-presenting, which has the effect of marking the present moment with the passage of time. "The contemporary" [...] thus has the effect of introducing an element of heterogeneity and difference into what is or should be homogenous, self-identical, the selfpresent as such'. 'Now, here, this', in Roger Luckhurst and Peter Marks (eds), Literature and the Contemporary: Fictions and Theories of the Present (Harlow: Longman, 1999), pp. 50-62 (p. 50).

${ }^{12}$ Luke Skrebowski discusses how Tino Sehgal's performance piece This is So Contemporary (2005) opens up a slightly different type of distinction, writing: 'it goes 
focuses on such relationality and, for instance, the darkness/light-within-the-present at the diegetic level, whilst also creating a distant proximity with its reader, may be considered a contemporary text par excellence. Whilst not unproblematic, such a reconsideration of the field would at least avoid the relative and potentially arbitrary splicing of chronology into literary periods, offering a more subjective, relational and temporally nuanced approach. Such an understanding of contemporary texts and readers would also go beyond the citational practices Agamben invokes towards the end of his essay, and it would thereby offer a more expansive formal account of contemporary textual relationality and reading - the very type of account I shall develop and explore in relation to Lerner's 10:04, a text concerned with reading and readers, as well as time and temporality.

\section{0:04's flickering darkness}

As with Agamben's essay, 10:04 is a text preoccupied with contemporariness and time, from its considerations of present-day life, to the temporality of literature, film and art, the presence-of-the-past in the present, the messianic and the apocalyptic. Telling the story of writer Ben, the text largely narrates Ben's observations, thoughts, his reading and writing habits, and the transformation of his observations into writing. Told in a realist fashion, Ben's narrative is very self-aware and 10:04 is highly metafictional, ultimately being the story of its

beyond the (now) traditional use of the term "contemporary" as a designator of the artistically coeval and instead seeks to constitute it as a stronger critical category, one that places demands on works to be adequate to the present (thus discriminating works that are merely coeval from those that are truly contemporary)'. 'Approaching the Contemporary: On (PostConceptual Writing', Amodern 6 (2016): http://amodern.net/article/approaching-thecontmeporary/ [Date accessed: 8 June 2018]. 
own creation. In a naïve sense, Ben is contemporary to and with his narrative world (New York and Marfa, Texas).

Beyond a quotidian understanding of 'contemporary' (in the sense of both the novel's publication date - for now, at least? - and the near-present-time setting of the narrative), 10:04 presents Ben's own contemporaneity, his own singular relationality to his present. Much of the narrative is focused on his sense of sight, and Ben is presented in the mode of commentator and poet-as-seer. The text's particular optics derive from Ben's poetic sensibilities, his intermittent use of drugs and the effect on his vision caused by Marfan syndrome. Together, these ocular aspects form a spectrum of light, sight and 'mis-seeing', with many of Ben's observations involving alterations in his vision ('a dozen prioceptive breakdowns flashed before me') and 'flickering' light - light that can be seen but only intermittently and which, therefore, involves its own non-light or darkness. ${ }^{13}$ Such light play also forms part of Ben's fascination with, and frequent recourse to, superimposition. For example, as he walks through a blacked-out Manhattan, he describes how 'the fireworks celebrating the completion of the bridge exploded above us in 1883 , spidering out across the page' (p. 239). In and through the darkness, Ben sees and cites the past, superimposing past and present, darkness and light, onto one another. Such a combination of optical destabilisation and temporal complexity also occurs throughout his many interactions with the visual arts, as when he reflects upon Donald Judd's sculptures at the Chinati Foundation in Marfa:

The work was located in the immediate, physical present, registering fluctuations of presence and light, and located in the surpassing disasters of modern times, Den Kopf

${ }^{13}$ Ben Lerner, 10:04 (London: Granta, 2014), p. 148. Hereafter cited in the text. 
benutzen ist besser als ihn verlieren, but it was also turned to an inhuman, geological duration, lava flows and sills, aluminum expanding as the planet warms. As the boxes crimsoned and darkened with the sunset, I felt all those orders of temporality - the biological, the historical, the geological — combine and interfere and then dissolve. I thought of the 'impossible mirror' of Bronk's poem. (p. 180).

Part of what Arne De Boever describes as the text's 'theme of reflection', ${ }^{14}$ Judd's artworks function both as an object of Ben's sight and an object of ekphrasis for the reader; they operate as a type of temporal looking glass and prism, arresting the viewer/reader with their temporal complexity. Ben discerns, and ultimately creates, a certain dishomogeneity by dividing the artwork between its position in the 'immediate present' (which in itself implies split and multiple presents), the historical time of its setting (a shed once used for prisoners of war), and the temporal layers of its materiality, which are beyond an anthropocentric gaze. Ben sees the temporal complexity of this art-object mirror, perceiving its more hidden, even if material, temporalities, observing the temporal darkness beyond and within its reflected light. With the turn towards sunset and thereafter darkness, moreover, he reflects the light and darkness of the object further by invoking William Bronk's poem 'Midsummer' (1955), which itself involves an ekphrastic reflection on reflection and the reciprocity of the gaze:

[...] One thinks how

in certain pictures, envied landscapes are seen

(through a window, maybe) far behind the serene

${ }^{14}$ Finance Fictions: Realism and Psychosis in a Time of Economic Crisis (New York: Fordham University, 2018), p. 177. 
sitter's face, the serene pose, as though

in some impossible mirror, face to back,

human serenity gazed at a green world

which gazed at this face. (p. 41)

By reflecting Judd's art object in the mirror that is Bronk's poem, Ben doubles his commitment to gaze at his present; as with Agamben's poet, he positions and presents himself as the engaged seer, gazing at both the light and the darkness within the present, the unseen in the seen, here distilled, reflected and refracted in and through art twice over. Standing between sculpture and reflected world, Ben is aware of his position within this type of caesural aesthetic scene. In relation to both the sculpture and the impossible reflection of Bronk's poem, he sees the type of relationality the contemporary needs to adopt and a way to inscribe himself. Moreover, his reflection brings sight, light, darkness and time together, compressed into an artistic/textual object of its own, 10:04, that in turn is reflected unto the reader.

Within the text, the epistemological privilege often granted sight is balanced and problematised by the promise and potential of non-sight or mis-seeing. Most notably, Ben goes to see the famous 'ghost lights' (p. 192) during his residency in Marfa but 'fails' to see these strange, naturally occurring, lights. Whilst standing on the constructed viewing platform (a metaphor for visual conformity), Ben does not see the lights that others see. Where others either see the lights or see nothing at all, he sees otherwise: literally, he sees the lights of fires in a different direction, and, more poetically, he 'sees' 'the ghost of ghost lights' (p. 194). Seeing differently, seeing the spectral absence of spectral presences, Ben once again emphasises his role as poet-as-seer or, indeed, non-negative non-seer, as 'to perceive this darkness is not a form of inertia or of passivity, but rather implies an activity 
and a singular ability' (Agamben, p. 45). Ben's particular non-vision gives him vision into a type of optical reciprocity: 'I saw no spheres, but I loved the idea of them - the idea that our worldly light could be reflected back to us and mistaken as supernatural' (p. 193). Moreover, he reflects and refracts this reflexivity, first by recalling Judd's reflective artworks - 'I fantasized that a couple of aluminum boxes were positioned in the distance to facilitate the mysterious radiance' - and further in his transformation of (non-)observation into verse:

$[\ldots]$ but why dismiss

what misapprehension can establish, our own illumination returned to us as alien, as sign? $[\ldots \ldots \ldots \ldots \ldots \ldots \ldots \ldots \ldots \ldots \ldots \ldots \ldots \ldots$

Tonight I see no spheres, but project myself and then gaze back, an important trick because the goal is to be on both sides of the poem, shuttling between the you and I. (p. 193)

Just as Agamben stresses that the 'special darkness' is not 'separable from those lights' (p. 45) of the present, Ben's vision and thought is fused with his 'negative' optics. As a poet, Ben recognises the promise of mis-seeing or 'misapprehending', of not being drawn into a positivistic reading based upon scientific knowledge; he is one "who knows how to see this obscurity, who is able to write by dipping his pen in the obscurity of the present' (Agamben, p. 44). Out of this particular obscurity, Ben transcribes how mis-seeing and the observation of darkness create a double refraction, in which illumination is differently illuminated, forming a mirror in which 'our' own light and time is reflected as other. As for the poetic 'I', it may 
not see the Marfa lights but projects itself through time in order to 'gaze back', thereby invoking Paul Klee's Angelus Novus, as well as Benjamin's famous reading of it (both of which feature in the text). Moreover, the poetic 'I' can be seen as a reflection of Agamben's poet, poetically creating - and expressing - its own singular relation with and to his present, a position he desires in the writing of poetry itself. Ultimately, then, Ben's optical, visual narrative is reflective and reflexive; he observes light and darkness and turns that light and darkness on himself and his own perceptual abilities.

Coinciding with, and created through, the diegetic focus on Ben's optics and his relationality to his present, the text itself is a type of obscure prism, in and through which the reader is directed to its lights and shadows, creating for her a sense of optical uncertainty. Ben, for instance, is himself a flickering presence in the narrative, a darkness-within-the-light of 10:04. He often doubts his own presence, experiencing 'bouts of depersonalization' (p. 148) and sensing himself as a spectral 'presence', 'like a ghost in the green hybrid' (p. 163). Such depersonalisation and spectrality are also part of Ben's writing process, especially during his work on, as he describes it, 'a weird meditative lyric in which I was sometimes Whitman' (p. 170). Metonymically, the flickering presence of Ben within the narrative gestures towards the relationship between Ben the narrator and Ben Lerner, the author of 10:04. As has been noted by reviewers and critics alike, the two Bens share certain similarities. Named only twice in the entire text, Ben's first name and profession, as well as details concerning published works and life events, provide a shadowy link to Ben Lerner. Notably, Alison Gibbons sees this relationship in optical terms. Writing about 'autofiction's stereoscopic effect', she argues that 'Lerner the author and Ben the character exist for readers 
as overlapping but ultimately irreconcilable phantasms of the authorial figure'. ${ }^{15}$ To alter the optics slightly here, 'Ben' and Ben Lerner are, I propose, shadows that throw darkness and light onto one another, creating a flickering figure that effects a sense of optical uncertainty; the reader 'sees' Lerner through Ben the narrator and Ben the narrator through Lerner, but the reader also does not see them as the same. The text is a caesura that brings the two figures together whilst holding them apart, a space in which the author is like the light of a galaxy that never reaches the reader and therefore appears to her as a type of (in)visible darkness. The relationship is a patterning of darkness and light that cannot be disentangled. Shining light on the fundamental authorial opacity at the centre of all narrative, this particular darkness-within-and-of-the-light also adds to the contemporary complexity of 10:04: the reader's confused relation to the character/diegesis, the narrator/narrative and the author/book, along with the non-coincidence of Ben and Ben Lerner, emphasises her own non-coincidence with the text itself. ${ }^{16}$

As with 'Ben' (character/narrator/author), the narrative of 10:04 also flickers. Rather than straightforwardly depicting events as they happen, the text often brings to light the

\footnotetext{
${ }^{15}$ Alison Gibbons, 'Autonarration, $I$, and Odd Address in Ben Lerner's Autofictional Novel 10:04', in Alison Gibbons and Andrea Mcrae (eds), Pronouns in Literature: Positions and Perspectives in Language (Palgrave Macmillan), pp. 75-96 (pp. 93, 85).

${ }^{16}$ For further readings of this authorial relationship, see: Daniel Katz, "“I did not walk here all the way from prose”: Ben Lerner's Virtual Poetics', Textual Practice 31.2 (2017), pp. 315-37 (pp. 316, 328); and Pieter Vermeulen, 'How Should a Person Be (Transpersonal)? Ben Lerner, Roberto Esposito, and the Biopolitcs of the Future', Political Theory 45.5 (2017), pp. 659-81 (pp. 666-7).
} 
potentiality (negative and positive) in the now. ${ }^{17}$ Most notably, the text emphasises this nonlinear potentiality via the representation and consideration of moments that end up not happening. For instance, the narrative contains two approaching storms that never arrive (the first not all and the second not for Ben, at least), which lead Ben to mark their significance temporally - 'as though we lived outside of history or were falling out of time' (p. 230). Beyond this somewhat simplistic sense of atemporality, Ben also considers related past moments in terms of 'retrospective erasure': 'Because those moments had been enabled by a future that had never arrived, they could not be remembered from this future that, at and as the present, had obtained' (p. 24). Such moments disclose for the reader the darkness-of-thelight inherent in the present, opening up the potentiality in and of the 'now'; they both partially erase lived pasts and give light to all those potential times that do not occur. At such points in the text, then, the reader is confronted with potentiality, not a straightforward account of what 'happened'; even in a fictional text, these moments and modes of narration create a sense of 'reality' being further disturbed, displaced and shadowy. Ben's 'poetics of modal instability' (p. 217) and his reflections on 'futures that do not happen' mark his distance from his present and create a sense of dislocation and reconfiguration for the reader. As with Agamben's view of the night sky, these diegetic moments unveil the light-in-and-ofthe-darkness of every event, narrated or otherwise.

The text's non-linear, reiterative and recursive structure further creates such displacement and distancing, with many moments occurring at least twice, often first as event

\footnotetext{
${ }^{17}$ In Homo Sacer, Agamben notes how, for Aristotle, potentiality 'is always also dynamis mē energein, the potentiality not to pass into actuality'. Homo Sacer: Sovereign Power and Bare Life, trans. Daniel Heller-Roazen (Stanford, CA: Stanford University Press, 1998 [1995]), p.
} 28. 
and then as textual transformation. Indeed, 10:04 enacts the type of 'transpositions' (p. 54) Ben sees at the heart of his short story for The New Yorker. Originally published in The New Yorker (18 ${ }^{\text {th }}$ June 2012), 'The Golden Vanity' is included in 10:04 as the second chapter, with much of its source material (seemingly) coming from events described in the first chapter. As a form of double transposition and reiteration, this inter-/intra-text is marked by 'repetition/alterity'. ${ }^{18}$ The tension between, and combination of, similarity and difference is, of course, temporally inflected, as re-iteration involves something happening again but also happening anew, at a different time, in a different-if-repetitious way. For the reader, such moments create a further tension in the text, then, between nearness and distance, as well as between familiarity and difference. The reader is displaced and fractured across (at least) two temporal moments, as re-iteration provokes memory of the first iteration.

These recursive and reiterative moments, this 'constellatory re-telling' as Skrebowski characterises it, ${ }^{19}$ are part of the text's more general citational concerns and poetics, functioning almost as types of self-citation. At the diegetic level, the text describes Ben's reading habits, as well as his thoughts about, and use of, citation. He points out to the reader, for instance, that he is quoting without indicating exactly what he is quoting (p. 238), and he offers his own astrophysical analogy concerning unattributed citation:

I find this less scandalous than beautiful: a kind of palimpsestic plagiarism that moves through bodies and time, a collective song with no single origin, or whose origin has

\footnotetext{
${ }^{18}$ Jacques Derrida, 'Signature Event Context', trans. Samuel Weber and Jeffrey Mehlman, in Gerald Graff (ed.), Limited Inc. (Evanston: Northwestern University Press, 1988), pp. 1-23 (p. 9).

${ }^{19}$ Skrebowski, 'Approaching the Contemporary: On (Post-)Conceptual Writing'.
} 
been erased - the way a star, from our earthly perspective, is often survived by its own light. (p. 114)

Through its own specific citational practice, 10:04 forms a highly (inter-)textual constellation, with citations, references and allusions to poems, novels, memoirs, films, paintings and art installations. Like the night sky, it is a text made up of light and darkness: it combines the bright light of overt referentiality and the more opaque, shadowy side of those allusions not referenced or underscored. Looking at this textual sky, the reader sees both the bright stars and the allusive darkness, and the intertextuality simultaneously brings together and creates a distance between the texts in this particular constellation. As such, the text acts as a type of caesura, positioning the reader within a fracture between it and its inter-texts. The reader is moved across the text(s), displaced from the ostensible focus on Ben's daily life, pulled away from 10:04's narrative towards the citations and inter-texts, which themselves pull the reader back to 10:04 - a process that creates, simultaneously, proximity and distance, darkness and light. Moreover, intertextuality and citation do not obey chronological time; the temporalities of the citations pulse within the text, and the text's temporality is, at such moments especially, neither simply linear nor singular; intertextuality 'urges, presses, and transforms' (Agamben, p. 47) textual time. Through this complex (inter)textuality, 10:04 emphasises its own contemporary relations - to the texts it cites and to the reader. Indeed, the allusions and citations open up light and dark fractures to the reader, making her relation to the text both close and distant, clear and opaque - non-coincident. ${ }^{20}$

${ }^{20}$ For a discussion of the citational practice and effects of Lerner's first novel, Leaving the Atocha Station (2011), see Katz, pp. 320-1. 


\section{'Contemporary' problematics}

Through its poetics of contemporariness, 10:04 provokes consideration of related contemporary problematics. Most notably, the text presses the scholar of the contemporary to think through questions concerning contemporary authors, readers and reading, and often does so through optical metaphors. It thereby illuminates the very darkness at the centre of Agamben's essay - how to be contemporary to or with a text - and, correlatively, how to approach the study of contemporary literature. For instance, through its depiction of Ben's meetings with his agent, his public readings, his time at the writer's residency and how a short story leads to an advance and an abandoned novel leads to 10:04 itself, the text makes visible both the vagaries of the literary economy and the various literary actors, networks and processes that, as Amy Hungerford explores in Making Literature Now, are often kept out of sight. ${ }^{21}$ At a fictional and metafictional level at least, 10:04 reminds the reader of the darkness-within-the-light of literary production. It encourages its reader to retain her gaze on the wider elements of literary creation, production and commodification - of the material object before her.

As part of its self-reflexivity concerning literary publishing, 10:04 also invites consideration of a further form of relation - the contemporaneity of contemporary writers.

\footnotetext{
${ }^{21}$ Significantly, Hungerford makes much use of visual metaphors throughout her study, ultimately proposing: 'By attending to the invisible and ephemeral in the present, the literary method I have practiced tries to resist that relentless abandonment of ideas, products, and workers'. Making Literature Now (Stanford, CA: Stanford University Press, 2016), p. 169. See Skrebowski for an analysis of how 10:04's self-reflexivity concerning economics and materiality forms part of its wider 'Institutional Critique'. See Arne De Boever for a reading of 10:04's specific economic and financial interests.
} 
During both one of the moments Ben fabricates the writerly correspondence that forms part of his original novel and one when he deletes it, he directly draws attention to issues of contemporaneity. In the first instance, he writes:

how else is one to find one's contemporaries, form a company? How else to locate the writers with whom one corresponds, both in the sense that we are corresponding now, and in that more general sense of some kind of achieved accord, the way we speak of a story corresponding with the facts? You no doubt know Jack Spicer's use of that term in all its weird possibility, how he corresponded with the dead, took dictation? And of course we have Baudelaire's sense of 'Correspondances'. (p. 128) ${ }^{22}$

As a fabricated form of correspondence that creates its own writerly correspondences, this interrogative reflection draws attention to the nuances of literary correspondence and contemporariness. Writing here as narrator-as-forger, Ben marks correspondence as a writing to. In less quotidian fashion, the notion of 'accord' points to non-chronological, nonsynchronic forms of writerly contemporariness; within this particular textual spatiotemporality, these correspondences cut across Baudelaire, Spicer, the forger characternarrator, the narrator Ben and the author Ben Lerner. This form of correspondence thereby offers a more intricate and nuanced understanding of contemporary authorship. It opens up a

\footnotetext{
${ }^{22}$ For a sense of Spicer's concept of poetic dictation, see: Jack Spicer, 'Dictation and "A Textbook of Poetry"', in Peter Gizzi (ed.) The House that Jack Built: The Collected Lectures of Jack Spicer (Middleton, CT: Wesleyan University Press), pp. 20-60. See, also, Charles Baudelaire's poem 'Correspodances' in Les Fleur du Mal (1857/1861).
} 
type of relational 'weird possibility' - across history and beyond chronology and linearity. When he deletes these fabricated letters, Ben 'un-writes' the following:

One should not—no rather cannot as a practical matter-expect one poet often to genuinely like the work of another - not a contemporary's. Even when we think we are writing to one another we are not writing for one another and so incomprehension is probably a necessity. We poets are not, as Oppen would say, coeval with each other, let alone our readers. It's in this sense the "public" is right to think of poets as anachronisms. (p. 212 $)^{23}$

This deleted text marks the impossibility of a certain type of accord: contemporary writers cannot, the deleted text posits and thereby simultaneously places 'under erasure', like the work of those writing in their own time. As if corresponding with Derrida's ideas concerning mis-delivery in 'Envois' (1980), the deleted correspondence also points to the impossibility of correspondence: writers cannot write 'for' one another even when they believe they are writing 'to' one another; incomprehension is, therefore, a necessary aspect of this form of relation. ${ }^{24}$ There always already exists, the deleted text marks, a sense of missing one another

${ }^{23}$ See 'Of Being Numerous' and 'Route' in George Oppen's collection Of Being Numerous (1968).

${ }^{24}$ Notably, Derrida writes to his addressee: 'And you are, my love unique / the proof, the living proof precisely, that a letter can always not arrive at its destination, and that therefore it never arrives'. The Post Card: From Socrates to Freud and Beyond, trans. Alan Bass (Chicago, IL and London: The University of Chicago Press, 1987), p. 33. 
within any form of writerly contemporaneity, which makes impossible any straightforward sense of writers being coeval. Underscoring the poet's non-coincidence, the forger-narrator marks the poet as anachronistic; non-relations between 'contemporary writers' set them aside from each other, and from the public. Under erasure, however, this passage ultimately raises these questions, rather than answers them; it is itself non-coincident with the remainder of the text of 10:04.

As with many aspects of the field of contemporary literary studies, the term 'contemporary writer' is often used simplistically to designate a writer writing now, or a recently dead or retired writer (despite debates about when, exactly, contemporary fiction starts), and 'contemporary writers' are often grouped together by chronology and period. However, Ben's fake correspondence calls into question the very notion of the contemporary writer and contemporary literary relations. Following both Agamben and 10:04, one way to re-conceive 'contemporary writer' would be to identify those texts that mark contemporary relationality. This would enable a more nuanced understanding of the term 'contemporary writer', as well as opening up contemporary relations between writers from different periods. This is not to say that there is an easy formula for designating such a 'contemporary' writer, or that all writers writing today are not in some basic sense contemporaries. However, a focus on relationality and 'dys-chrony' would provide a different approach and methodology, a different set of questions to consider. Such a proposition introduces at the very least a fold, a crease, for the scholar of the contemporary to consider; it presents another way to group writers and therefore to rethink the field of contemporary literary studies, offering new lines of connection and different markers of delimitation.

As part of its intricate crucible, 10:04 also brings to the fore relations between writer and reader, and text and reader - the very blind spots in Agamben's essay. Through the narrator's fascination with Walt Whitman and Whitman's 'future' reader, and through his 
own, direct addresses to the reader - 'You might have seen us walking' (p. 8), 'You might have seen me sitting there on the bench that midnight' (p. 109), 'Reader, we walked on' (p. $234)$ - the text repeatedly acknowledges the reader, the 'other side' of the text, as it were. ${ }^{25}$ For instance, when Ben 'fails' to see the Marfa lights, he tells the reader:

I thought of Whitman looking across the East River late at night before the construction of the bridge, before the city was electrified, believing he was looking across time, emptying himself out so he could be filled by readers in the future; I took him up on his repeated invitations to correspond, however trivial a correspondent I might be. (p. 194)

Forming a connection through and between his and Whitman's gaze and their ocular situations, Ben positions the poet as an expressive force, whose poiesis and writing require correspondence with, and fulfilment by, future readers. By so doing, Ben becomes the correspondent he sees himself as, creating a contemporary relation between the two writers separated 'across' time. Filtered through mis-seeing - 'the ghost of ghost lights' - Ben sees in the darkness forms of correspondence. For him, Whitman is a type of light and darknessin-the-light of the present, and by extension, for the reader of 10:04 itself; Whitman is a contemporary writer for Ben (and Ben Lerner), much more so than are many of their peers those 'contemporary writers' writing today.

\footnotetext{
${ }^{25}$ For a discussion of address in one of 10:04's main intertexts, Whitman's 'Crossing Brooklyn Ferry' (1856/1881), as well as in Lerner's works more widely, see Katz, pp. 328,
} 333-5. 
The reflection on Whitman's future reader and Ben's use of address also open up the question of reading and textual time, as well as text-reader relations. Moving from the diegetic and extradiegetic concern with readers to the text itself, 10:04 has at least three types of reader. Each adopting a different temporal mode, they are: the one who has read it; the one reading it now; and the one who will read it in the future. The middle one, perhaps, conforms to a pedantic and overdetermined definition of 'contemporary reader', whereas the outer two point to more nuanced, folded views of temporal-textual relations. The text emphasises and enacts this multi-dimensional conceptualisation of 'contemporary readers' through the narrative depictions of Ben's own reading (especially of Walt Whitman) and through the reading of 10:04 itself. In terms of the reader-yet-to-come, 10:04 invokes and anticipates and its own future reading, most explicitly through its metafictional modes and moments, such as: 'Say that it was standing there that I decided to replace the book I'd proposed with the book you're reading now' (p. 194). It thereby encourages its reader (and contemporary scholars) to consider the relationship between the present and future, as well as how the future may form part of the 'contemporary' itself. ${ }^{26}$

As well as the three basic temporal demarcations of 10:04 readers - past, present, future -, the text also points to the 'negative reader': the one who has not read, the one who is not reading, and the one who will not read the text. Most strikingly, the narrative ends with

\footnotetext{
${ }^{26}$ Whilst texts from all periods can encourage this, the scholar of the contemporary travels in ways unlike those of other literary periods. Rather than thinking about how, for example, the Victorian novel is received by its twenty-first-century reader, the scholar of the contemporary is impelled to think about the near-future. The end point of the contemporary is not now but in a minute, at least; there is a sense of a future-within-the-present, which makes the future an important concern within the field.
} 
Ben, partly mimicking President Reagan's television address to the nation following the Challenger spacecraft disaster, declaring: 'I want to say something to the schoolchildren of America' (p. 239). Rhetorical, yes; but this address is somewhat disingenuous, as it is unlikely that many or, indeed any, schoolchild will read 10:04; 'schoolchildren of America' is a syntagm for the 'non-10:04-reading majority'. The schoolchildren Ben 'addresses' are (non-)present addressees, as opposed to the reader of 10:04. Consequently, the text anticipates and posits its own non-reading, creating a further fold in the consideration of 'the contemporary reader', and one literary academics tend to ignore - the reader who is not reading and will not read the text under discussion. ${ }^{27}$ Just as a schoolchild will not receive the address at the end of 10:04, most of those alive today will never even hear of 10:04. In the study of contemporary literature - used here in the sense of literature written, published and read today - scholars must, then, consider further types of darkness-within-the-light of the field: fellow scholars who will not read the novel under discussion; 'general' readers who will not read the text; those who do not read literature; and, perhaps most importantly, those who cannot read. Indeed, acknowledgement of the illiterate should form part of contemporary

${ }^{27}$ Whilst the topic of non-reading has recently been taken up with interest, it is still the case that most literary criticism does not acknowledge, address or consider those who have not read the text(s) under consideration. In his exploration of non-reading, Pierre Bayard devises a notation system to indicate his relation to the books under discussion: $\mathrm{UB}=$ 'book unknown to me'; $\mathrm{SB}=$ 'book I have skimmed'; HB = 'book I have heard about'; FB = 'book I have forgotten'. Unsurprisingly, perhaps, this is not a system widely adopted, if at all, by scholars. How to Talk About Books You Haven't Read, trans. Jeffrey Mehlman (New York: Bloomsbury, 2007). For a discussion of her decision not to read David Foster Wallace and what she terms 'critical not-reading', see Hungerford, pp. 141-67. 
literary studies, if only to put the field in perspective, to show a certain important 'darkness' within the 'bright lights' of the literary and scholarly community. To consider those who do not read is, as it were, the obverse side of the work carried out by James F. English, for one, on the scale of publishing and the consequent number of books that go unread. ${ }^{28}$ As with unread books, those who do not read tell us something about scale and scope. Not only do we read an ever-shrinking percentage of texts being published, and not only do we talk to a tiny percentage of the population, but we also study and analyse objects that many cannot access or read. ${ }^{29}$ Of course, this is not to say that what scholars of the contemporary do is not valuable! But 10:04's address to a readership that will not read the text, and ideas relating to non-reading and illiteracy more broadly, at least provide some further problematics to consider in the study of contemporary literature. Such aspects may, indeed, offer the

${ }^{28}$ According to English, 'by even the most conservative estimate there have been between one and two million new works of adult fiction published in English in the last fifty years'. Consequently, he contends, there are 'hundreds of thousands of effectively readerless novels'. 'Now, Not Now: Counting Time in Contemporary Fiction Studies', Modern Language Quarterly 77.3 (2016), pp. 395-418 (p. 402). For similar accounts, see: Hungerford, pp. 142-3; Matthew Wilkens, 'Contemporary Fiction by Numbers', Post45 (2011). http://post45.research.yale.edu/2011/03/contemporary-fiction-by-the-numbers/ [Date accessed: 31 August 2017].

${ }^{29}$ According to UNESCO, in 2016 around $14 \%$ of the world's adult population and $9 \%$ of the world's youth population, 'lack[ed] basic reading and writing skills'. UNESCO, 'Fact Sheet No. 45', (September 2017), pp.1-13 (p. 1). http://uis.unesco.org/sites/default/files/documents/fs45-literacy-rates-continue-risegeneration-to-next-en-2017.pdf [Date accessed: 29 June 2018]. 
coordinates for a different type of map of contemporary literary studies, opening up different ways to think about 'contemporary readers' that touch on critical issues such as gender, ethnicity, education and wider geopolitics. ${ }^{30}$ With hope, we should also contemplate a world in which illiteracy is practically non-existent and how such a scenario may change the way we think about contemporary literary studies. ${ }^{31}$

As with the unread, so too the deleted or un-written. 'Dear Ben, I deleted' (p. 210) marks Ben's un-writing of his novel about a falsified correspondence. Ben decides to pursue a new novel - 'the book you're reading now, a work that, like a poem, is neither a fiction nor nonfiction, but a flickering between them' (p. 194) - and erase the planned one. The narrated act of deletion, of un-writing, 'presents' the reader with a text 'under erasure', at least for those parts being deleted within the narrative that are therefore visible. Whilst both mundane and generic - because all acts of literary creation involve editing and deletion - this moment in the text raises a significant theoretical problematic. As Agamben writes in 'Experimentum Linguae', his preface to Infancy and History (1978), 'every written work can be regarded as the prologue (or rather, the broken cast) of a work never penned' ${ }^{32}$ In relation to $10: 04$, there is a threefold instantiation of prologue-to-written text: diegetically, the deleted text is a type of prologue to the one that is written; inversely, 10:04 acts as a type of prologue - however obliquely - to the one deleted; and 10:04, like all written texts, is a prologue to a text never

\footnotetext{
${ }^{30}$ For example, $2 / 3$ of the adult illiterate population are women. UNESCO, p. 1.

${ }^{31}$ According to UNESCO, '50 years ago, almost one-quarter of youth lacked basic literacy skills compared to less than $10 \%$ in 2016 '. UNESCO, p. 1.

${ }^{32}$ Infancy and History: On the Destruction of Experience, (London and New York: Verso, 2007), p. 3.
} 
written, which is 'unplaceable in any precise chronology'33 and not the one deleted in the narrative. This other text is forever 'unplaceable' and presents a further temporal fold in 10:04, providing another darkness-within-the-light of the text. The text un-written flickers within 10:04 itself, seen and unseen simultaneously. ${ }^{34}$

As well as being both a further 'presence' within the text and providing a further theoretical complexity, this metafictional moment of deletion-and-creation also points to an important practical concern within the field of literary studies. It is common critical practice to consider textual differences between drafts, editions, notes, etc., and the increasing use of computational methods in the Digital Humanities has led to further forms of corpus and textual variants analysis. But this moment in 10:04 raises another form of scholarly imperative: to reflect upon the un-written. Practically, this is of course somewhat impossible (just as Agamben's contemporariness is itself often posited as an impossibility), and certainly not the same as doing archival work or digital computational comparisons or data analysis. ${ }^{35}$ Indeed, archival work and certain forms of the Digital Humanities pursue forms of presence,

\footnotetext{
${ }^{33}$ Agamben, Infancy and History, p. 3.

${ }^{34}$ For analysis of 10:04's final words, which come from a line of 'Crossing Brooklyn Ferry' Whitman removed from the 1891-2 version of Leaves of Grass, see: De Boever, p. 167,
} Gibbons, pp. 92-3, and Katz, pp. 328-9.

${ }^{35}$ Nick Thurston deftly expresses this type of impossibility in his discussion of illegibility more widely, writing: 'Reading il/legibility poses an oxymoron. Given the mutual exclusivity of said intention (to read) and its object (the unreadable), any attempt to read the illegible should combust at an impasse before it can be said to have begun'. 'Reading the Illegible', Amodern 6 (2016). http://modern.net/article/reading-the-illegible/ [Date accessed: 17 May 2018]. 
even eliciting and permitting a certain fetishisation of the archive and its contents - of what is. Essentially, these approaches are concerned with making things visible. In contrast, focusing on the (un-)written moves the scholar away from the archive, the draft, the note; the un-written is an absence that cannot be recovered through textual excavation. It is, rather, the light that never reaches us, the darkness-of-the-light-of-the text. Despite - or, indeed because of, - this difficulty, the un-written text should be seen as part of the darkness-of-the-light of the contemporary, and it should therefore be considered if a reader (unlike Agamben in his essay) hopes to be in some way contemporary with a text. ${ }^{36}$

The field of literary studies is, moreover, composed of the unseen in at least two senses: in addition to the un-written text, there is the unwritten as well as the unwritten/deleted scholarship - the mass of 'no-longer-existent' material - that also comprises the light-and-darkness of the literary-critical field. Moreover, what gets published on contemporary literature may be more blinded to the light of the present than it is able to see the darkness, or the light-of-and-within-the-darkness. Whilst Robert Eaglestone is probably right to claim that within contemporary literary studies 'it is not that there is a consensus: there is not even a disensus [sic] ${ }^{37}$ concerning the problematics to address, to meet editorial

${ }^{36}$ Correlatively, Ruffel writes in his exploration of contemporary literary culture: '[Agamben's] approach unites two perspectives of cultural theory. It's no longer a matter of canonizing or classicizing contemporary phenomena, as in some literary studies, nor is it a matter of picking out the stars — the "great author" or the "great artists" — but neither is it a matter of using a sociological or quantitative approach; rather, it's a matter of establishing a state of the visible together with the invisible'. Ruffel, Brouhaha, p. 79.

37 'Contemporary Fiction in the Academy: Towards a Manifesto', Textual Practice 27.7 (2013), pp. 1089-1101 (p. 1093). 
and peer approval the operation of certain norms and modes of conformity (involving both consensus and dissensus), must be in place (however tacitly and invisibly); consequently, we may all simply be seeing and reflecting the same present light, rather than seeing the darkness that would enable us to be and respond to the contemporary in more 'contemporary' ways. Maybe those of us who claim to be contemporary scholars are in fact the least contemporary of all, blinded by our own shared light, continually building a bright consensus. Perhaps scholars of the contemporary 'coincide too well with the epoch' (Agamben, p. 41) and are lost in the light of present consensus; we are 'in the dark' about contemporary literary culture, but it is a darkness we cannot see, gaze upon or comprehend, even though we must. By writing on this well-known novel by a well-known present-day writer alongside the lights of a well-known present-day philosopher, I am, of course, guilty of looking at certain bright lights, of trading in highly visible forms ${ }^{38}$ But, to bend or refract the light once more, I want to propose that by casting the darkness within Agamben's highly visible essay - his own blind spots concerning reading and readers - over and through my reading of 10:04, I may at least have pointed to a certain patterning of darkness-within-and-of-the-light of contemporary literary studies, a constellation of (in)visibility that, at the very least, deserves our gaze.

\footnotetext{
${ }^{38}$ Indeed, I am operating within what Hungerford describes as the narrow 'celebrity system' of textual selection. Hungerford, pp. 14-16. Moreover, this essay focuses on a novel by a white man, which, according to Emily Hyde and Sarah Wasserman, tends to be the subject of most book-length critical work in the field of contemporary literary studies. 'The
} Contemporary', Literature Compass 14.9 (2017), p. 3. https://doi.org/10.1111/lic3.12411 [Date accessed: 26 February 2018]. 